\title{
Tıbbi ve Aromatik Bitkiler Vadisi Tasarımı: Şanlıurfa Örneği
}

\author{
Hülya Öztürk Tel ${ }^{1 *}$ \\ 1* Harran Üniversitesi, Şanlıurfa Teknik Bilimler MYO.Mimari Restorasyon Bölümü, Şanlıurfa, Türkiye (ORCID: 0000-0001-9277-9119), hulyaozturktel@gmail.com
} (İlk Geliş Tarihi 9 Eylül 2021 ve Kabul Tarihi 23 Kasım 2021)

(DOI: 10.31590/ejosat.993481)

ATIF/REFERENCE: Hülya Öztürk Tel. (2021). T1bbı ve Aromatik Bitkiler Vadisi Tasarımı: Şanlıurfa Örneği. Avrupa Bilim ve Teknoloji Dergisi, (27), 1118-1131.

$\ddot{\mathbf{O z}}$

Günümüzde kentsel açık ve yeşil alanlar, doğa ile yakınlaşma imkanının en fazla olduğu alanlardır. Tıbbi aromatik bitki bahçeleri; araştırma, bitki çeşitliliğini koruma, rekreasyon ve eğitim alanlarında faaliyet gösteren mekanlardır. Çalışmada, Şanlıurfa kenti için Harran Üniversitesi Şair Nabi Yerleşkesi'ne hem üniversitenin hemde halkın kullanımına sunulabilecek, "Tıbbi ve Aromatik Bitki Vadisi” peyzaj tasarımı önerisi geliştirilmiştir. Alanın mevcut kullanım durumu, çevre analizleri ile belirlenmiş, alana ilişkin avantaj ve dezavantajları saptanarak, kullanıcı ihtiyaçları ve tasarım süreci ortaya konulmuştur.

Bu çalışmanın amacı; Şanlıurfa kenti için sürdürülebilir, bütüncül bir peyzaj tasarımıyla doğal çevre ile insanların yakınlaşmasını sağlayarak, tıbbi aromatik bitkiler konusunda farkındalık yaratmaktır. Bu amaç kapsamında; gözlem, arazi çalışmaları, leke planı, tasarım yaklaşımı ve ön tasarım, kesin tasarım ve bitkilendirme tasarımı aşamalardan oluşan bir dizi çalışma gerçekleştirilmiştir.

Sonuç olarak, çalışmanın uygulanması ile Şanlıurfa kenti ve GAP ölçeğinde önemli bir açık ve yeşil alanın oluşumuna katkı sağlanarak, biyolojik çeşitlilik korunacaktır.

\section{Design of the Valley of Medicinal and Aromatic Plants: The Case of Şanlıurfa}

\begin{abstract}
Today, urban open and green spaces are the areas where the opportunity to get closer to nature is the most. Medicinal and aromatic herb gardens; are places operating in the fields of research, plant diversity protection, recreation and education. In the study, a landscape design proposal for the city of Şanlıurfa, "Medical and Aromatic Plant Valley", which can be presented to the use of both the university and the public, has been developed for Harran University Şair Nabi Campus. The current use of the area has been determined by environmental analysis, the advantages and disadvantages of the area have been determined, and the user needs and design process have been revealed.

The aim of this study; To create awareness about medicinal and aromatic plants by bringing people closer to the natural environment with a sustainable and holistic landscape design for the city of Şanlıurfa. Within the scope of this purpose; A series of studies consisting of observation, field studies, spot plan, design approach and preliminary design, final design and planting design were carried out. As a result, with the implementation of the study, biodiversity will be protected by contributing to the formation of an important open and green area in Şanlıurfa city and GAP scale.
\end{abstract}

Keywords: Medicinal Aromatic Plant, Medicinal Aromatic Plant Garden, Landscape Design Project, University Campus, Therapy Garden.

\footnotetext{
* Sorumlu Yazar: hulyaozturktel@,gmail.com
} 


\section{Giriş}

İnsan nüfusunun kent merkezlerinde yoğunluk kazanması ile açık yeşil alanlar azalmakta, insanların doğaya özlemleri daha da artmaktadır. Bu nedenle kent içinde ve sınırında tasarlanan açık yeşil alanların çoğaltılması ve korunması gittikçe önem kazanmakta olup, bu alanlar insanlara bir çok aktivite sunmaktadır (Fuller, vd., 2007; Gülgün, vd., 2014). Kentlerde önemli açık yeşil alanlarından biri de tıbbi ve aromatik bitki bahçeleridir. Tıbbi ve aromatik bitki bahçeleri; çok çeşitli tıbbi ve aromatik bitki türlerinin bir araya getirildiği açık hava müzesi, eğitim ve rekreasyon alanı niteliği taşımaktadır.

Tıbbi ve aromatik bitki bahçelerinin amacı; tıbbi ve aromatik bitkileri araştırmak, üretmek, kültüre alınmasını sağlayarak, biyoçeşitliliği geliştirmek, halkın tıbbi ve aromatik bitkileri tanımasını sağlamak ve faydalarının bilinmesi sağlamak, rekreasyon alanı oluşturmak, floradan faydalanma konusunda katkı sağlamaktır.

Tıbbi aromatik bitkilerin kullanımı çok eski olup, antik dönemden günümüze kadar bir çok kullanım alanına sahip olmuştur. Özellikle insanlar eski dönemlerden beri tıbbi aromatik bitkilerin kullanımına önem vererek tedavi amaçlı, sağlıklı yaşayabilmek, hastalıkları önlemek veya iyileştirmek için ondan yararlanmıştır (Pouya ve Demir, 2017). Tıp biliminin gelişmesi ile şifa bulma amacı ile kullanılan ilaçların hammaddesi tıbbi ve aromatik bitkiler olmuş, bu bitkilerin önemi giderek artarak, büyük bir pazar haline dönüşmüştür (Baytop, 1999).

Bitkiler doğrudan şifa veren ilaçların hammaddesi olarak kullanılıyorsa tıbbi bitki; koku ve tat katacak madde olarak kullanılıyorsa aromatik bitki; hem tıbbi olarak hastalıkları tedavi etmekte, hem de diğer alanlarda kullanılıyor ise tıbbi ve aromatik bitki olarak kabul görmektedir (Anonim, 2021a). Dünya Sağlık Örgütü ve Birleşmiş Milletler'e göre hastalıklara karşı direnç ve tedavi edici özelliği olan ve insanların sağlıklı olmasını sağlayan bitkiler tıbbi aromatik bitkiler olarak tanımlanmıştır (Oran, 2015; Marshall, 2011; Ersöz, 2012; Kırıc1, 2015).

Bu bitkilerin kök, gövde, yumru, sap, kabuk, yaprak, çiçek, meyve ve tohumları kullanılarak hazırlanan çay, baharat, aromatik su, çeşni olarak beslenmede; uçucu yağ, pomat, macun, parfüm, krem olarak kozmetikte, tedavi eden ilaçların hammaddesi olarak sağlıkta kullanılmaktadır (Faydaoğlu ve Sürücüoğlu, 2011; Erbaş, 2013; Arslan, vd.,. 2015; Dönmez vd., 2016; Pouya ve Demir, 2017; Temel, vd., 2018; Kösa ve Güral 2019).

2000'li yıllarda çok sayıda yeni tıbbi ve aromatik bitki türlerinin yetiştirilmesi, kültüre alınması ve üretilmesi, ticaretin küreselleşmesi ile günümüzde ihracatı artmıştır ( Khan, vd., 2005),

Türkiye, sahip olduğu ekolojik koşullar nedeniyle, bitki türleri açısından zengin florası ile çok çeşitli tıbbi ve aromatik bitki türlerine sahiptir. Türkiye florasında 9000'in üzerinde bitki türü bulunup, bunun yaklaşık 1000 tanesi tıbbi ve aromatik kökenli bitkilerdir. Özellikle Güneydoğu Anadolu Bölgesi tıbbi ve aromatik bitkilerin gen merkezi konumundadır. Ancak tıbbi aromatik bitki zenginliği verimli şekilde kullanılmamaktadır (Oran, 2015; Faydaoğlu ve Sürücüoğlu, 2011; Anonim, 2021a; Anonim, 2021b).

İnsanlar, bitkileri önceleri beslenme ve sağlık gibi temel ihtiyaçlarını gidermek amacıyla kullanmışlar ancak zamanla görsel ve estetik duygulara hitap ettiklerinden yetiştirerek "Tıbbi e-ISSN: 2148-2683 ve aromatik bitki bahçesi" olarak da adlandırılan bahçeler oluşmuştur (Gülgün, vd., 2009). Bu bitkiler süs bitkisi olarak çiçek güzellikleri ile peyzaj tasarımlarında alternatif bitki olarak değerlendirilmektedir (Dönmez, vd., 2016; Pouya ve Demir, 2017; Kösa ve Güral, 2019). Tıbbi bitkiler bahçeleri, Ortaçağ Avrupa'sında dualara eşlik etme, ruhani etkileri ve iyileştirici etkilerinden dolayı manastır bahçelerinde yaygın bir şekilde kullanılmıştır (Leszczynski, 1997; Arslan, 2010; Serez, 2011).

Tıbbi ve aromatik bitkiler; peyzaj tasarımlarında formları, renkleri ve dokuları ile duyularını harekete geçirmekte, kokuları koku duygusunu, tatları tat duyusunu teşvik etmektedir. Tıbbi aromatik bitki bahçelerinde sergileme yapılarak, türler keşfedilebilmekte ve bilimsel araştırmalar için laboratuvar niteliği taşımaktadırlar (Kösa ve Güral, 2019; Surat, 2020 )

Tıbbi ve aromatik bitkiler, estetik ve işlevsellik açısından çok önemli fonksiyonlara sahip olup, koleksiyon bahçeleri, terapi bahçeleri, botanik bahçeleri, kaya bahçeleri, çatı ve teras bahçeleri, saksılar gibi farklı alanlarda kullanım olanakları bulmaktadır (Sarı ve Karaşah, 2019). Terapi ve şifa bahçeleri, toplu kompozisyonlar halinde bitkilerin kullanıldığı, insanların duyularını harekete geçirerek iyileştirici, rahatlatıcı, dinlendirici etkisi olan önemli bir bahçe çeşididir (Keçecioğlu, 2014). Hoş kokulu bitkiler ile koku alma hissi, farklı dokulara sahip bitkiler ile dokunma hissi, estetik açıdan yaprak, çiçekler ve meyve güzelliği ile görme hissi, ürünlerin toplanması ve tadı da tad duyusunu teşvik ederek iyileştirme etkileri vardır. Peyzaj düzenlemelerinde kullanımlarına önem verilmesi gerekmektedir (Düzenli, vd., 2017; Bekar ve Gülpınar Sekban, 2018; Gülpınar Sekban, 2020 ).

Tibbi ve aromatik iyileştirme ve terapi bahçelerinde bitkilerin görsel değerlerini oluşturan dokusu, formu, gövde ve yapraklanma yapısı da tasarımda aktif rol oynamalıdır. Özellikle bir eğitim kurumuna bağlı bulunan tıbbi aromatik bitki bahçeleri, eğitici ve bilgi verici özelliklerinin yanında, doğa ve çevre bilincini geliştirici nitelikleri de olmalıdır (Hepcan ve Özkan, 2005). Önemli eğitim kurumları olan üniversite yerleşkeleri bulunduğu kent için oldukça önemli açık yeşil alanlar olup, rol model görevi üstlenmektedir (Y1lmaz ve Irmak, 2012). Üniversite yerleşkeleri açık-yeşil alan planlamaları ile bulundukları kente ekolojik, ekonomik, kültürel, estetik ve rekreasyonel katkılar sağlayan alanlardır (Yılmaz, 2019). Üniversite yerleşkelerinde tıbbi ve aromatik bitki bahçelerinin kurulması, yerleşkenin yeşil alan miktarını arttırarak sosyalleşmeye teşvik ederek, zihinsel yorgunluğu azaltır. $\mathrm{Bu}$ amaçla yapılan çalışmada Güneydoğu Anadolu bölgesinin önemli kentlerinden biri olan Şanlıurfa kent merkezinde yer alan Harran Üniversitesi Şair Nabi Yerleşkesi'nde "Tıbbi Aromatik Bitkiler Vadisi Peyzaj Projesi" çalışması önerilerek, mevcut durum ve tasarım süreci ortaya koyulmuştur. Verimli topraklar üzerine kurulmuş olan Harran Üniversitesi Şair Nabi Yerleşkesi'nin tıbbi ve aromatik bitki vadisine peyzaj tasarımı önerisi getirilerek, yeşil alan oranının arttırılması, halk, üniversite akademik /idari personeli ve öğrencileri için alternatif yeşil alan olarak kullanılması amaçlanmıştır. Yanı sıra, tıbbi aromatik bitki türleri kullanılarak kullanıcıların farkındalığını arttırmak ve ekonomik sürdürülebilirliğe katkı sağlamak hedeflenmiştir.

Ayrıca kentte kurulacak olan tıbbi ve aromatik bitki vadisi, rekreasyonel ihtiyaçlara katkı sağlayarak kent için önemli bir açık yeşil alan ihtiyacını karşılamış olacaktır. 


\section{Materyal ve Metot}

\subsection{Materyal}

Çalışma alanı; Şanlıurfa ili sınırları içinde, Haliliye merkez ilçesinde, Şanlıurfa Mardin karayolunun 10. km'sinde, Göbeklitepe yolu güzergahında bulunan Harran Üniversitesi Şair Nabi Yerleşkesi'nin $150.000 \mathrm{~m}^{2}$ 'lik arazisinin $50.000 \mathrm{~m}^{2}$ 'lik tasarıma konu olan alanda gerçekleştirilmiş̧ir (Şekil 1).

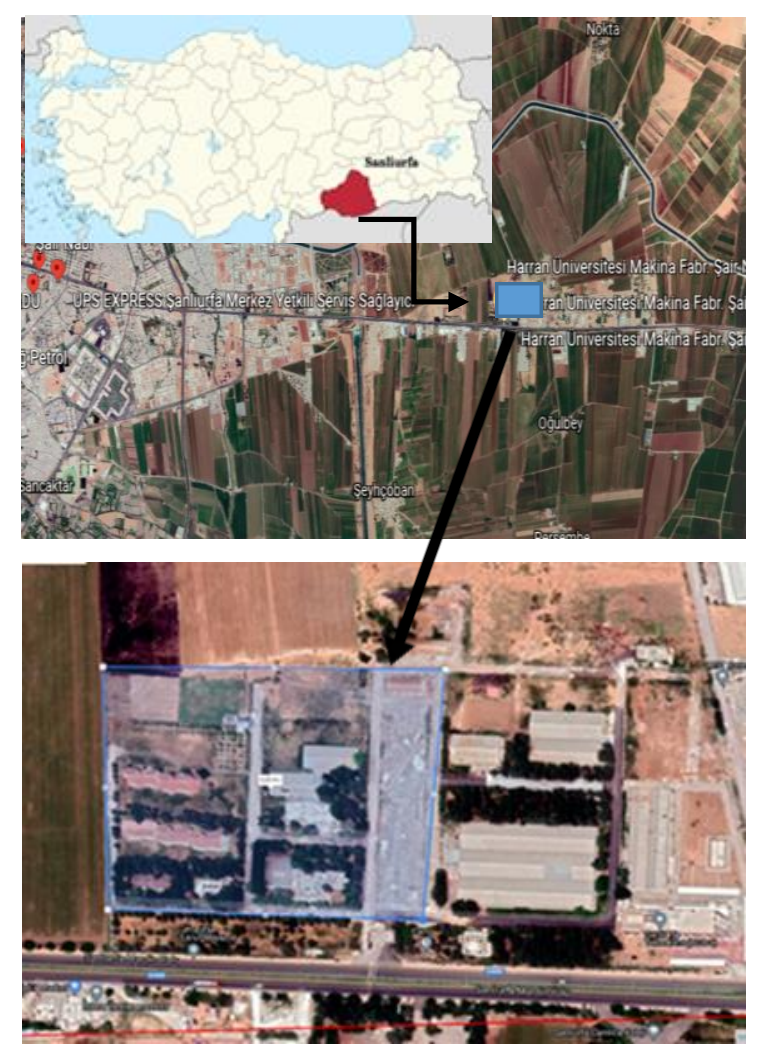

Şekil 1. Çalışma alanın konumu

Çalışmada alana ilişkin vaziyet planları, topografik harita, fotoğraflar ve yetkililer yapılan görüşmeler yardımcı materyal olarak değerlendirilmiştir. Öneri projelerin çiziminde AutoCAD 2018, SketchUp and Lumion programları kullanılmışıtır.

\subsection{Metot}

Çalışmada, Şair Nabi Yerleşkesi'ne yeni işlev verilerek, hem üniversitenin hem de halkın kullanımına sunulabilecek, "Tıbbi Aromatik Bitkiler Vadisi Peyzaj Projesi” çalışması önerilmiş, mevcut durum ve tasarım süreci ortaya koyulmuştur.

Alanın peyzaj tasarım projesinin hazırlanmasında yöntem olarak; Bartlett, vd., 2014; Sağlık ve Kelkit, 2015; çalışmalarından yararlanılarak, aşağıdaki aşamalardan oluşmaktadır;

- Çalışma alanının seçimi, amaç ve sorunları belirleme

- Mevcut durumu tespit etme ve veri toplama

- İhtiyaç listesi oluşturma

- Leke planı oluşturma

- Tasarım yaklaşımı ve ön tasarım

- Kesin tasarım

\section{- Bitkilendirme tasarımı}

Çalışmanın ilk aşamasında tıbbi ve aromatik bitkilerle ilgili çalışmalar, tıbbi aromatik bitki bahçelerinin yurt içi ve yurt dışındaki bazı örnekleri irdelenmiştir.

İkinci aşamada alanın çevresel özellikleri, kullanıcı eğilimleri ve üniversite yönetiminin talepleri doğrultusunda, yeni bir peyzaj tasarımının yapılmasına karar verilmiştir. Üniversite yönetimi ve teknik personellerle tasarım aşamasında istişarelerde bulunularak öneri "Tıbbi Aromatik Bitkiler Vadisi Peyzaj Projesi” oluşturulmuştur. Öneri olarak sunulan peyzaj tasarımı projesinin yapımı konusunda özellikle finansman sağlayacak olan Şanlıurfa Büyükşehir Belediyesi ile Harran Üniversitesi arasında işbirliği için görüş̧meler devam etmektedir

\section{Araştırma Sonuçları ve Tartışma}

T1bbı Aromatik Bitkiler Vadisi peyzaj projesinin hazırlanmasında peyzaj tasarım aşamaları aşağıdaki başlıklar altında incelenmiştir.

\section{1. Çalışma Alanının Seçimi, Amaç ve Avantaj- Dezavantajlarının Belirlenmesi}

Tıbbı Aromatik Bitkiler Vadisi peyzaj projesinin hazırlanmasında peyzaj tasarım aşamaları aşağıdaki başlıklar altında incelenmiştir.

Çalışma alanı olarak, Şanlıurfa Harran Üniversitesi Şair Nabi Yerleşkesi seçilmiştir.

$\mathrm{Bu}$ yerleşkenin seçilmesinde;

Toprak yapısının verimli olması, etrafının tarım yapılabilen verimli arazilerle çevrili olması ve tıbbı aromatik bitkilerin ekim ve yetiştirilme tarlaları için olanak sunması,

Yerleşkenin halk, öğrenci, akademik ve idari personelin serbest zamanlarını geçirebileceği konum ve büyüklükte olmasına rağmen, işlevleri yerine getirecek estetik ve fonksiyonel alt ve üst yapı elamanlarının bulunmaması yeni tasarımların yapılabilmesi için firsat olmuştur.

$\mathrm{Bu}$ yerleşkeye yeni bir işlev verilerek; tıbbi ve aromatik bitkiler vadisi olarak yeniden tasarlanması amaçlanmaktadır. Bu amaç doğrultusunda çalışma alanının avantaj ve dezavantajları Tablo 1 'de verilmiştir. 
Tablo 1. Çalışma alanının avantaj ve dezavantajları

\begin{tabular}{|l|l|}
\hline \multicolumn{1}{|c|}{ Çalışma Alanının Dezavantajları } & \multicolumn{1}{|c|}{ Çalışma Alanının Avantajları } \\
\hline Alanda herhangi bir kentsel donatı elemanı bulunmamas1 & $\begin{array}{l}\text { Harran Üniversitesi Şair Nabi Yerleşkesi’nin işlev verilebilecek } \\
\text { alanlara sahip olması ve değerlendirilebilecek mevcud } \\
\text { bitkilerinin bulunması }\end{array}$ \\
\hline $\begin{array}{l}\text { Alanda oturma, dinlenme vb. rekreatif faaliyetlerin } \\
\text { yapılabileceği mekanların bulunmaması }\end{array}$ & $\begin{array}{l}\text { UNESCO tarafindan Dünya Kültür Mirası Geçici Listesi'nde yer } \\
\text { alan Göbeklitepe yol güzergahında olması Göbeklitepe'ye gelen } \\
\text { ziyaretçiler için turizm rotası olması }\end{array}$ \\
\hline & $\begin{array}{l}\text { Kente 10 km lik yakın bir mesafede ve doğa ile bütünleşik olması } \\
\text { Alanın ve çevresinin ekim yapılabilir verimli topraklara sahip } \\
\text { olması ve çevresinde kentleşmenin olmaması, }\end{array}$ \\
\hline
\end{tabular}

\subsection{Mevcut Durumu Tespit Etme ve Veri Toplama}

Proje çalışmasına başlanılmadan, çalışma alanında yerinde incelemeler yapılarak alanın mevcut durumu saptanmış, gerekli proje altlıkları hazırlanarak, sörvey çalışması gerçekleştirilmiştir. Bu aşamada çalışma alanın çevresini tanımak amacı ile özellikle gözlem ve ölçüm yapılmış, fotoğraf çekilmiş, yetkili kişiler ve üniversite yönetimi ile görüşülmüştür. Toplanan bu bilgiler vaziyet planı üzerinde belirtilerek "sörvey çalışması" oluşturulmuştur. Sörvey çalışmasıyla alana ilişkin mevcut durum ortaya konulduktan sonra tasarlanacak etkinlik alanlarının yerleri arazinin imkanlarına göre konumlandırılmıştır.

Harran Üniversitesi Şair Nabi Yerleşkesi; Harran Üniversitesi'nin kent merkezindekien eski yerleşme olup,. Osmanbey Yerleşkesi'nin ana yerleşke olması ile bu yerleşkede, yaklaşı son 5 yıldır eğitim-öğretim faaliyetlerinin yapılmamaktadır. Çalışma alanının doğusunda, geçmişte tarım aletlerinin yapımı için kullanılan fabrikalar yer almaktadır. (Şekil 2.

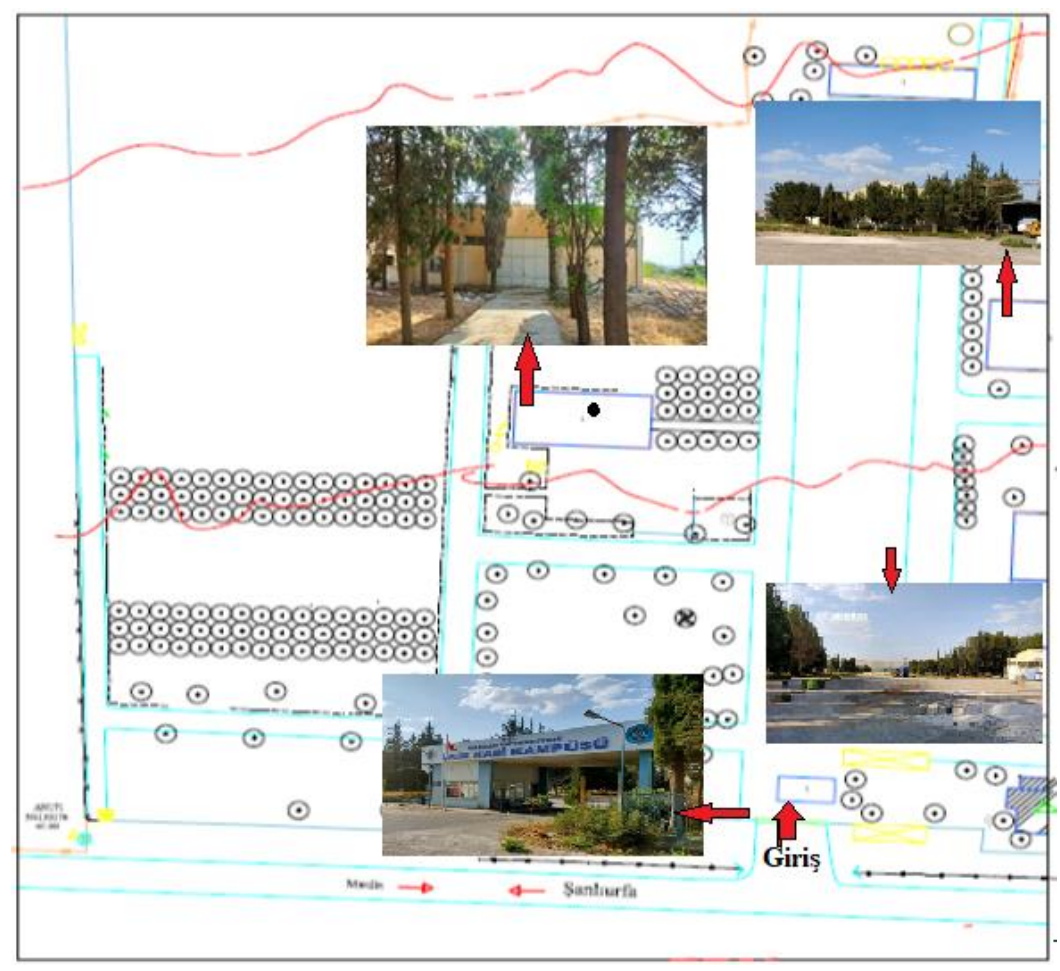

Şekil 2.Alanın halihazır durumu, eğimi ve işlevlendirilebilecek fabrikalar (Anonim,2021c) 
Alanın kuzeyi ve batısı verimli arazilerle çevrilidir. Alanın kuzeyinde bulunan $100.000 \mathrm{~m}^{2}$ lik verimli arazi Harran Üniversitesinin mülkiyetinde olup, tibbi aromatik bitkiler için ekim ve yetiştirme alanlarına dönüştürülmesi düşünülmektedir

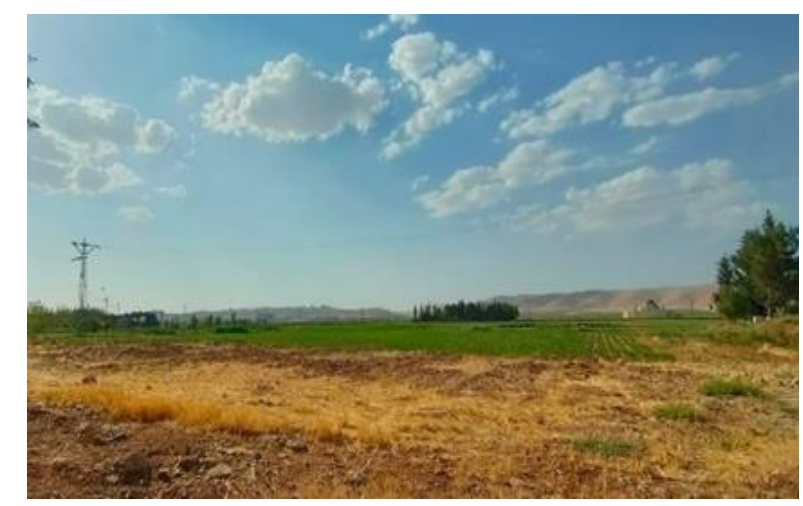

Şekil 3. Çalışma alanının çevresindeki verimli tarlalar

Yeşil dokuda ise rastgele dikilmiş bitkiler ve bakımsız yeşil alanlar bulunmaktadır. Bu bitki türleri; Cupressus sempervirens L. (Servi), Ailanthus altissima (Mill.) Swingle (Kokarağaç), Washingtonia robusta H.Wendl. (meksika yelpaze palmiyesi), Thuja plicata (boylu mazi), Thuja orientalis"pyramidalis"(piramit mazı), Cedrus atlantica (mavi
(Şekil 3). Çalışma alanı olarak seçilen Şair Nabi yerleşkesi; oldukça düz bir topoğrafyaya sahip olup, alanın ortasında $50 \mathrm{~m}$ genişliğinde ve 300 metre uzunluğunda bir sert zemine sahiptir (Şekil 4).

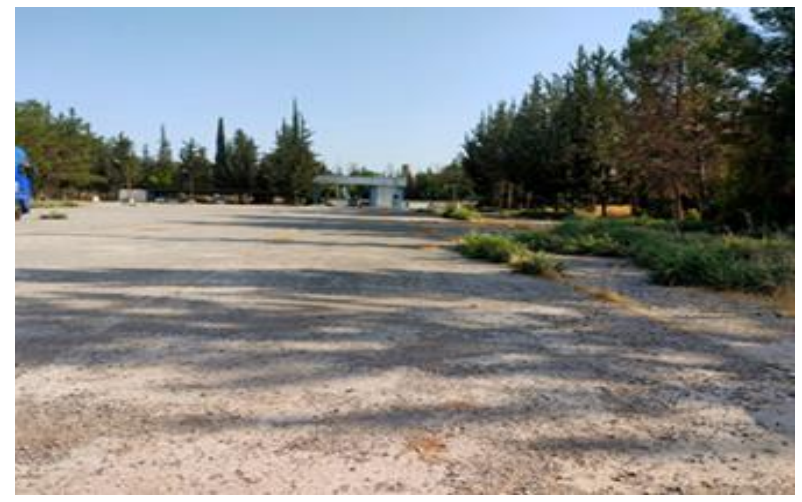

Şekil 4. Alanda bulunan geniş sert zemin

atlantik sediri), Pinus nigra Arnold. (karaçam), Ligustrum japonicum Thunb. (Japon Kurtbağr1), Rosa sp.(gül) ve Nerium oleander L. (zakkum) 'dur (Şekil 5).

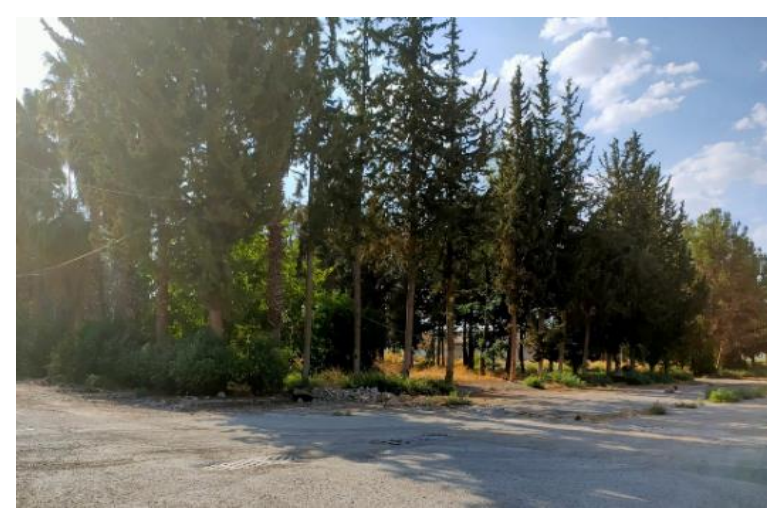

Şekil 5. Alanda mevcutta bulunan bitkiler ve yeşil alanlar

\section{3. İhtiyaç Programı Oluşturma}

İnsanın bir mekanda, bir etkinliği gerçekleştirmesi için mekanın bu etkinliğe uygun olması gereklidir. Bunun sağlanabilmesi için, ihtiyaç-etkinlik-mekan ilişkisi iyi kurgulanmalıdır (Yılmaz, 2015). Bu aşamada, alan ve çevresinde bulunan çevresel faktörler irdelenerek, bu faktörlere göre

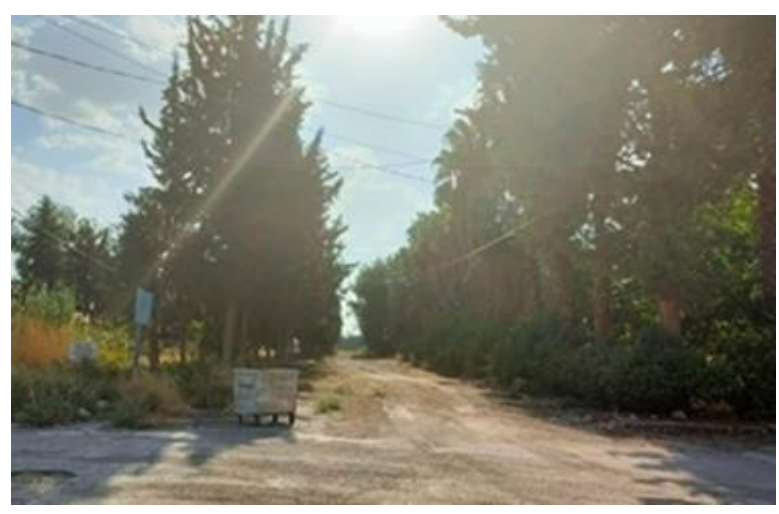

kullanımlar getirilmiştir. Alanda tespit edilen sorunlara ilişkin çözüm önerileri geliştirilerek, ihtiyaçlara yönelik "ihtiyaç programı" hazırlanmıştır (Tablo 2).

Tablo 2. İhtiyaç programında yer verilen kullanımlar

\begin{tabular}{l}
\hline Ihtiyaç programında yer verilen kullanımlar \\
\hline T1bbi aromotik bitkiler vadisi konseptine uygun giriş \\
\hline T1bbi aromatik bitki dikim parselleri ve sergileme alanı \\
\hline T1bbi aromatik bitkiler ekim ve yetiştirme tarlaları \\
\hline T1bbi aromatik ürün satı̧ birimleri \\
\hline Ekolojik okul \\
\hline Restorant ve cafe
\end{tabular}




\begin{tabular}{l}
\hline Mevcut korunacak bitkiler \\
\hline Toplanma, oturma, izleme ve dinlenme alanı \\
\hline Gölgeleme birimi \\
\hline Çiçek parterleri \\
\hline Otopark alanı \\
\hline Tibbi aromatik bitki işleme fabrikası \\
\hline Üretim serası \\
\hline
\end{tabular}

\subsection{Leke Planı Oluşturma}

$\mathrm{Bu}$ aşamada, ihtiyaç listesinin belirlenmesi ve alanın mevcut durumu ve analizine göre, uygun yerlere alan kullanımlarının lekeler halinde ölçeksiz olarak yerleştirilerek, Tibbi Bitkiler Vadisi leke planı elde edilmiştir (Şekil 6).

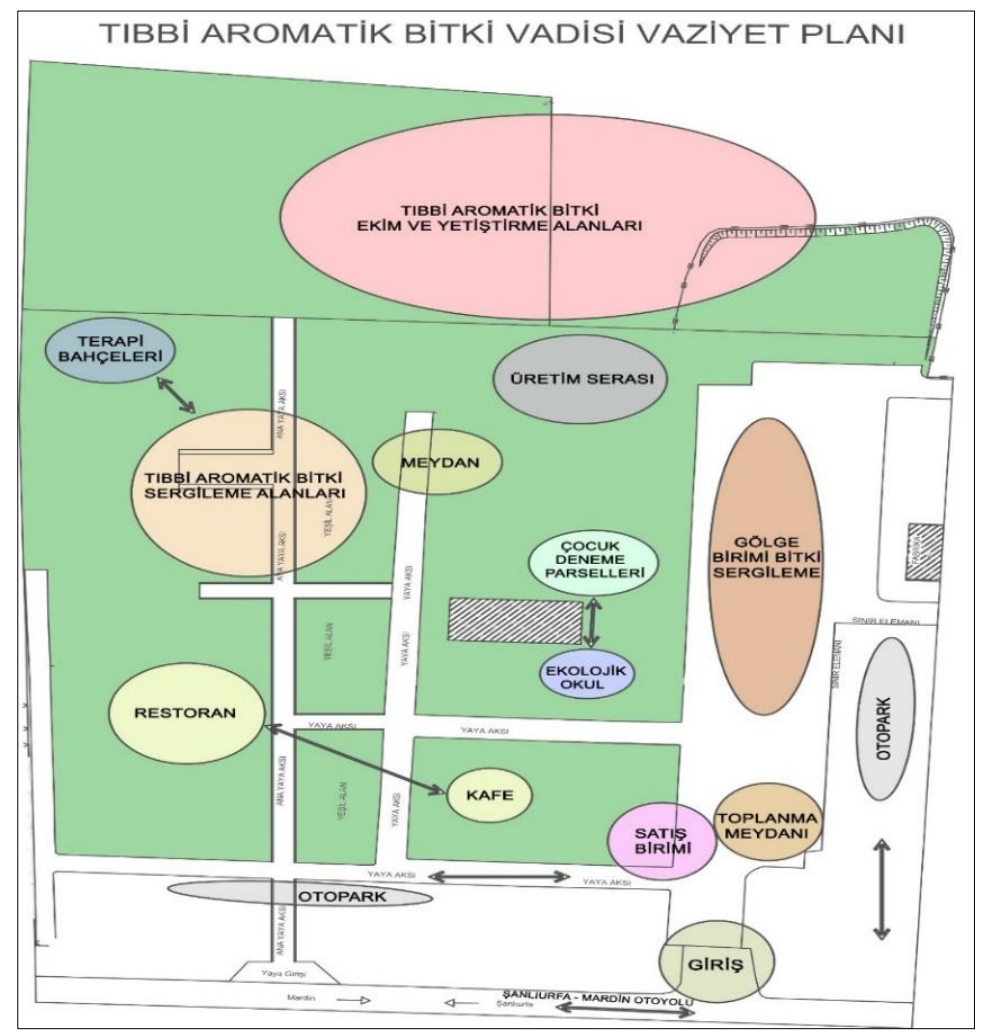

Şekil 6. Leke planı

\subsection{Tasarım Yaklașımı Ve Ön Tasarım}

Tasarıma yön veren yaklaşım saptanarak, Leke planında belirtilen kullanımların proje üzerine ölçekli olarak aktarılması ile tasarıma yönelik ana kararlar, fonksiyonların ilişkilendirildiği ön proje hazırlanmıştır.

Çalışmada tasarıma yön veren yaklaşım;

- Eğitime katkı sağlama ve toplum bilincini arttırma; Türkiye tıbbi ve aromatik bitkiler açısından zengin floraya sahip olmasına rağmen uzmanları, halkı ve çocukları bu konuda bilinçlendirilebilecek mekanlar bulunmamaktadır.

Tıbbi ve aromatik bitki dikim parselleri ve sergileme alanına gerekli bilgilendirme tabelalarının konumlandırılması ile bu bitkilerin öğrenimi kolaylaşmaktadır (Yoğunlu, 2011). Bu bilgilendirme tabelalarında tıbbi aromatik bitkilerin ne şekilde kullanılacağına dair bilgilere yer verilmesi toplum bilincini arttırarak doğa ile insan arasındaki bağı kuvvetlendirir.
- Toplumsal sağlığı artırma; hem bitkilerle doğal tedavi ile insanlar sağlığına kavuşurlarken, hemde tasarımda yer alacak terapi bahçeleri ile bitkilerin koku, görsel etkileri ile rahatlamalarına olanak sağlayacaktır.

- Türlerin devamlılığına katkı sağlama ve peyzaj tasarımlarında bitki tür çeşitliliğini arttırma; Türkiye'de yöre halkı tarafından tıbbi amaçlı kullanılan çok fazla tıbbi aromatik tür bulunmasına rağmen bu türlerin çok azı kültüre alınarak üretimleri yapılmaktadır. (Kevseroğlu, vd., 2014).Yapılan etnobotanik çalışmalarda bu türlerin saptanarak kültüre alınması türlerin sürdürülebilirliği açısından önemlidir. Peyzaj tasarımlarında tıbbi aromatik bitkilerin kullanımına önem verilerek, bitki tür çeşitliliği arttırabilir.

- Ekonomiye katkı sağlama; bitkilerin fabrikada işlenmesi ile tibbi aromatik bitkilerden yağ, çay, kozmetik vb. ürünlerin elde edilmesi sağlanabilir. Bu ürünlerin ihracatı ile ülke ekonomisine katk1 sağlanabilir. 


\subsection{Kesin Tasarım}

Alanda yapılan, mevcut durumu tespit etme, sorunları belirleme ve veri toplama, ihtiyaç listesi ve leke planı sonucu şekillenen ön tasarım geliştirilerek peyzaj tasarım projesi/kesin proje hazırlanmıştır.

Yapılan peyzaj tasarımı sonucu alanda yapılması planlanan mekan ve etkinlikler; tıbbi ve aromatik bitki dikim ve sergileme parselleri, ekim ve yetiştirme alanları, üretim serası, tıbbi ve aromatik bitki işleme fabrikası, giriş ve danışma birimi, ekolojik okul ve restoran, toplanma meydanı, tıbbi aromatik ürün satış birimleri, gölgeleme birimi, terapi bahçesi, oturma birimleri, yürüme yolları, otopark ve donatı elemanlarıdır (Şekil 7, Şekil 8, Şekil 9).

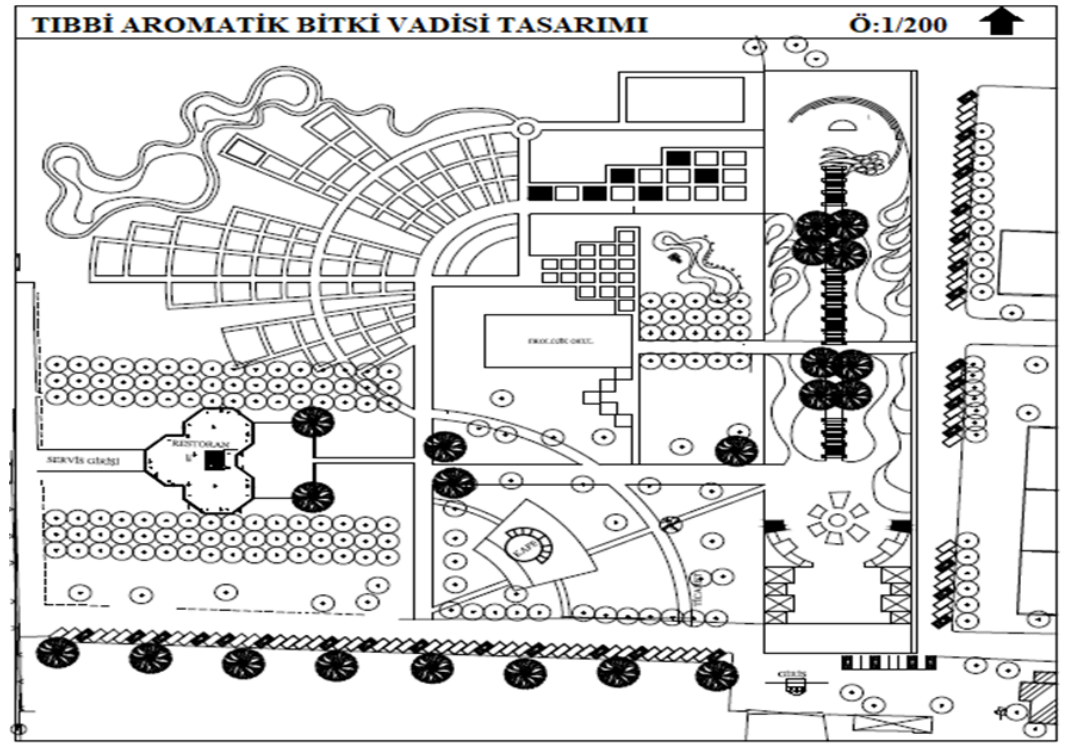

Şekil 7.. Öneri proje çalışmasının planı

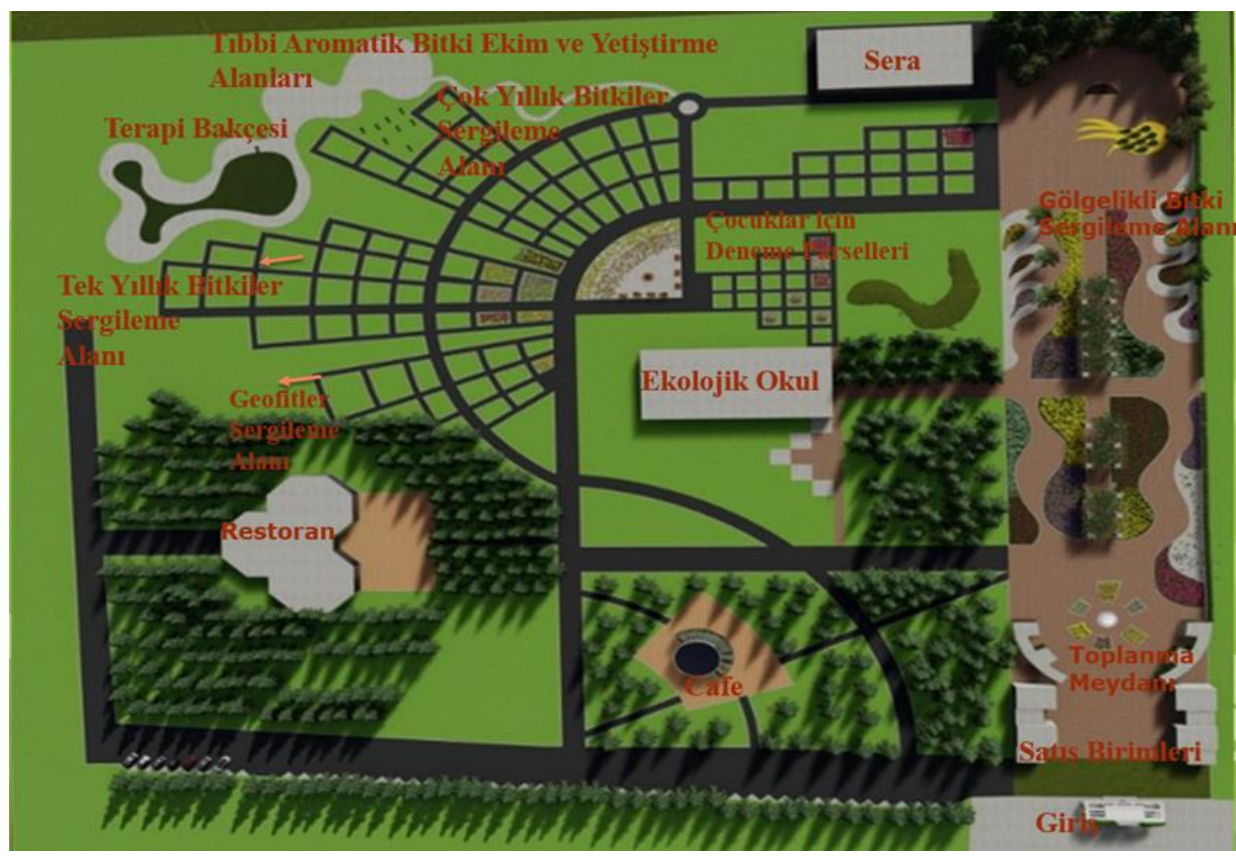

Şekil 8. Öneri proje çalışmasının görselleştirmeleri 


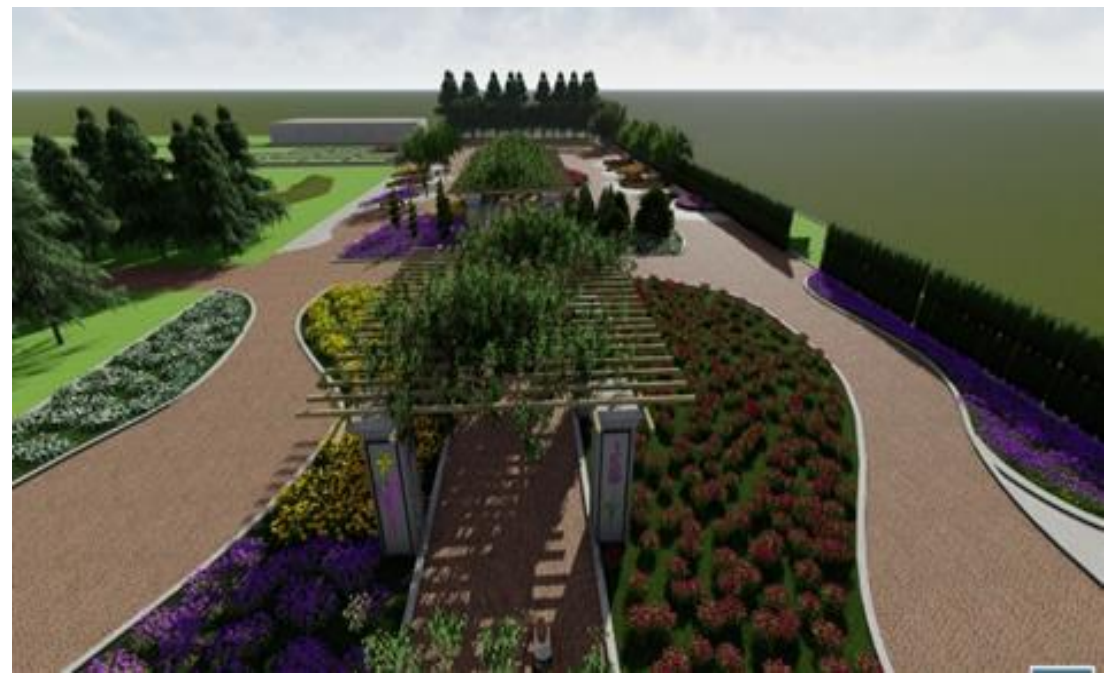

Şekil 9. Gölgelikli bitki sergileme alnanının görselleştirmeleri

3.6.1. Tibbi ve Aromatik Bitki Dikim Ve Sergileme Parselleri, Ekim Ve Yetiştirme Alanları, Üretim serası, Tıbbi ve Aromatik Bitki İșleme Fabrikası

Projenin ana teması tıbbi aromatik bitkiler olduğundan bu kapsamda proje alanında yapılan gözlemler ve literatür taramalarından elde edilen veriler doğrultusunda tıbbi aromatik bahçelerde bitki dikim ve sergileme parselleri tasarlanmıştır. Tıbbi aromatik bitkilerin tek yıllık, çok yıllık ve geofit bitki dikim alanlarından oluşup, giriş kısmında bulunan gölge elemanının

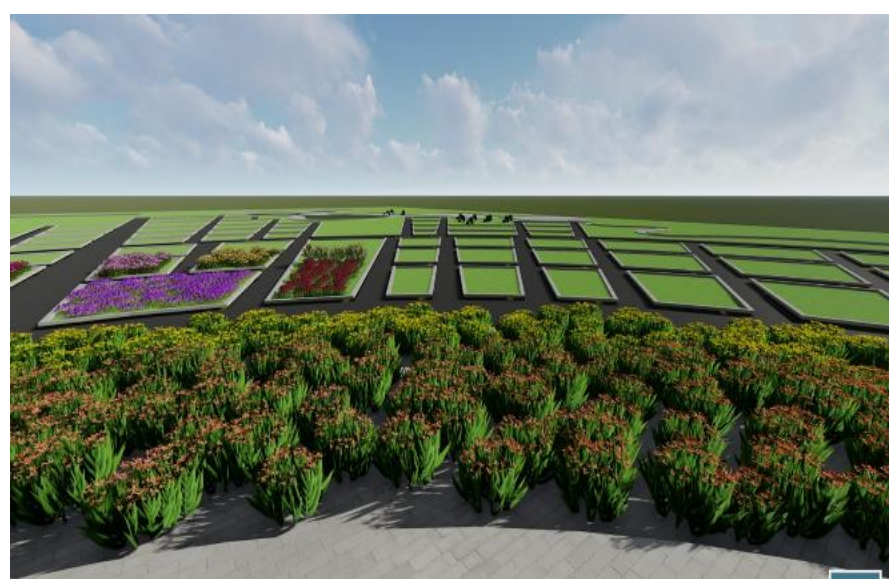

kenarlarında yörede doğal olarak yayılış gösteren tıbbi aromatik bitkilerden çiçek güzelliği olan türler tercih edilmiştir. Ziyaretçilere tanıtım tabelaları ile bitkilerin tanıtımlarının yapılması sağlanabilecektir. Arzu eden ziyaretçilerine telefonlarına ilgili programı indirip, QR kodunu okutarak ayrıntılı ve sesli bilgi alabilmesine olanak sağlayacak şekilde tasarım kararı geliştirilmiştir. Alan yönetim planı oluşturularak, randevulu şekilde okullar veya özel grupların gezebilmesi konusunda planlama yapılması gerekmektedir (Şekil 10).

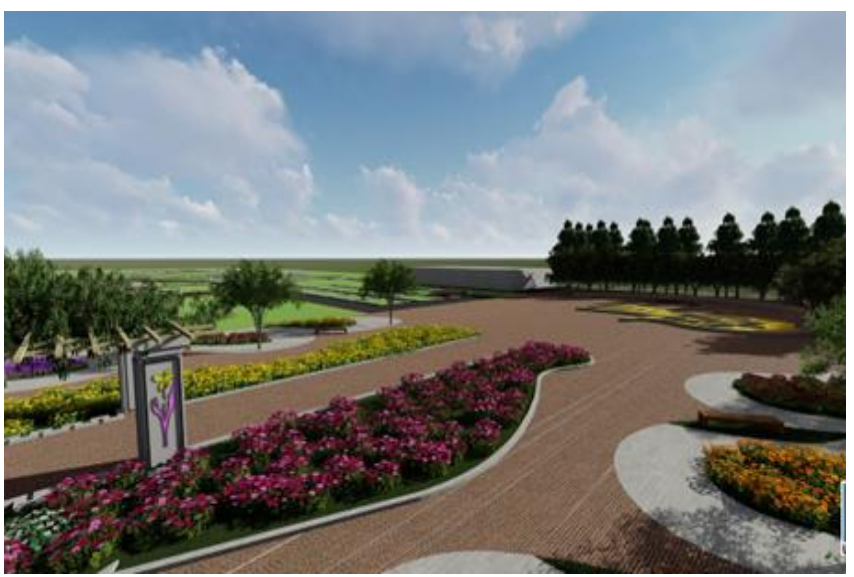

\section{Şekil 10. Tıbbi ve Aromatik Bitki Dikim Ve Sergileme Parselleri}

Ekim ve yetiştirme alanlarl; tıbbi aromatik bitki vadisinin kuzeyinde yer alan 100 dönümlük verimli alan ekim ve yetiştirme alanları için uygundur. Bu alanda tarlalara ekilen tıbbi aromatik bitkilerin hasadı gerçekleştirilerek tıbbi ve aromatik bitki işleme fabrikasına gönderilmesi mümkündür.

Üretim serasında; özellikle tek yıllık otsu tıbbi ve aromatik bitkilerin değişimlerinin her yıl yapılması gerektiğinden bu bitkilerin tohumdan veya çelikten üretimleri bu serada yapilabilecektir.
Tıbbi aromatik bitki işleme fabrikası ise çalışma alanın doğusunda yer alan fabrikaların, tıbbi aromatik bitkilerin işlendiği fabrikaya dönüşümü kararı verilmiştir.

Dönüştürülen fabrika için yeni işlevler olarak, bitkilerin tıbbî amaçla kullanılan kısımları kurutulup, paketleme yapılması, uçucu ve sabit yağ elde edilebilmesi, merhem, krem, parfüm, kolonya, sabun üretimi yapılması önerilmektedir. Tıbbi aromatik bitkilerden aynı zamanda; tıbbî çay, tıbbî macun, otlu ekmek ve kurabiye, doğal reçel, sirke, turşu, şerbet, sos, bitkisel enerji içeceği üretimi de yapılması sağlanabilir. Tıbbi aromatik bitki işleme fabrikasında; personel, stajyer ve kursiyerlerin faydalanması mümkündür (Şekil 11). 


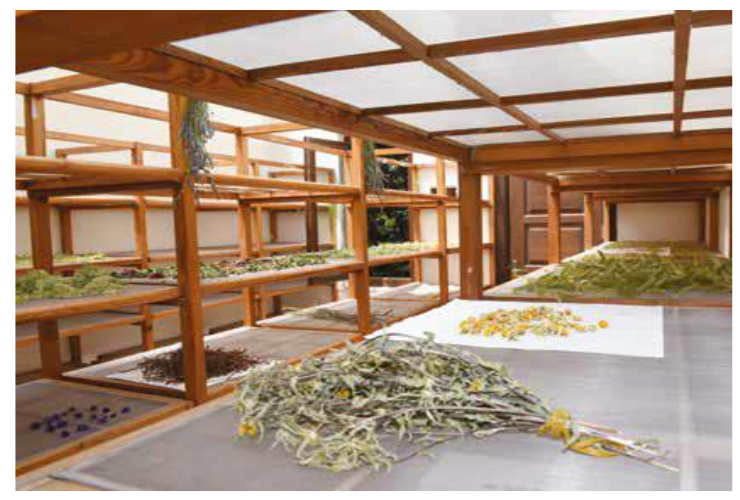

Şekil 11. Işslev değişikliği önerilen tıbbi aromatik bitki işleme fabrikası iç mekan detayı (Çekin, vd., 2016)

\subsubsection{Giriş Ve Danışma Birimi}

Proje alanında giriş ve çıkışın güvenlik açısından kontrollü olması için bir adet giriş- çıkışın sağlandığı birim tasarlanmıştır. Bu girişin ortasında danışma ve güvenlik, sağında ve solunda kontrollü yaya ve araç giriş-çıkış yolları tasarlanmıştır. Ana giriş tasarımında; etkili renk ve bitki formuyla bir tasarım yapılmasına özen gösterilmiştir. Şanlıurfa'da buğday bitkisinin ilk olarak Göbeklitepe eteklerinde 12 bin y1l önce yetiştirilmesi sebebi ile giriş kapısının formu buğday başağı şeklinde simgesel bir tasarım yapılmasına karar verilmiştir. Şanlıurfa -Mardin yolundaki hızlı akan trafikte insanlar için girişin algılanabilir olması önem taşımaktadır (Şekil 12).

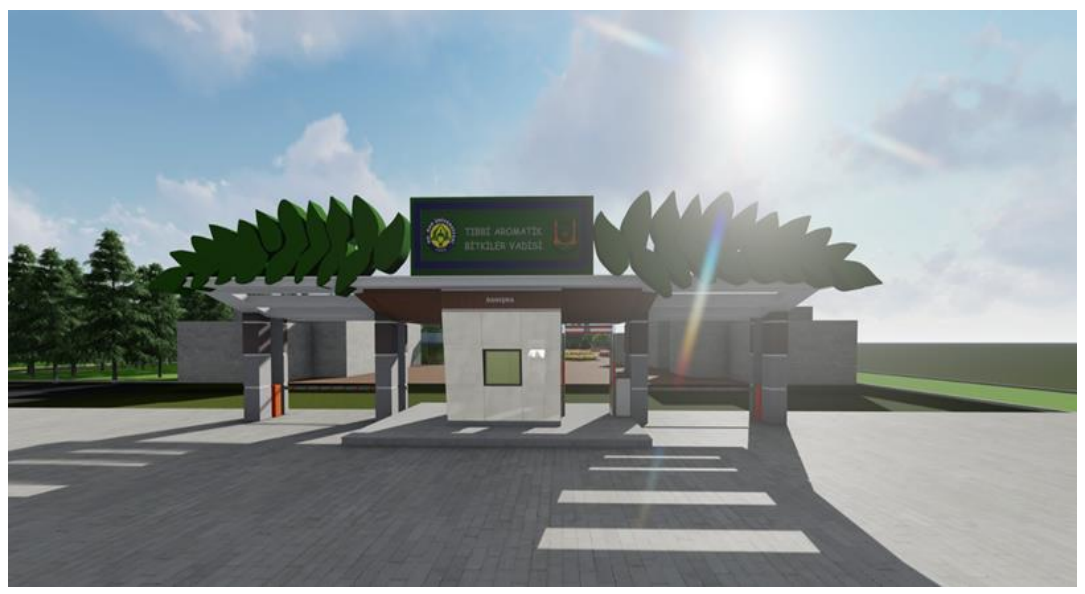

Şekil 12. Öneri giriş kapısı tasarımı

\subsubsection{Ekolojik okul ve restoran}

Çalışma alanının merkezinde bulunan günümüzde kullanılmayan binanın dönüşümü sağlanarak ekolojik okul olarak tasarlanması kararı alınmıştır. Çocuklar için doğal tepe ve kütüklerden yapılan oyun alanı, bitki ekim ve dikim yapabilecekleri bitki ekimleri yapabildikleri gibi, beş duyu ile algılanan bitkileri keşfedilerek

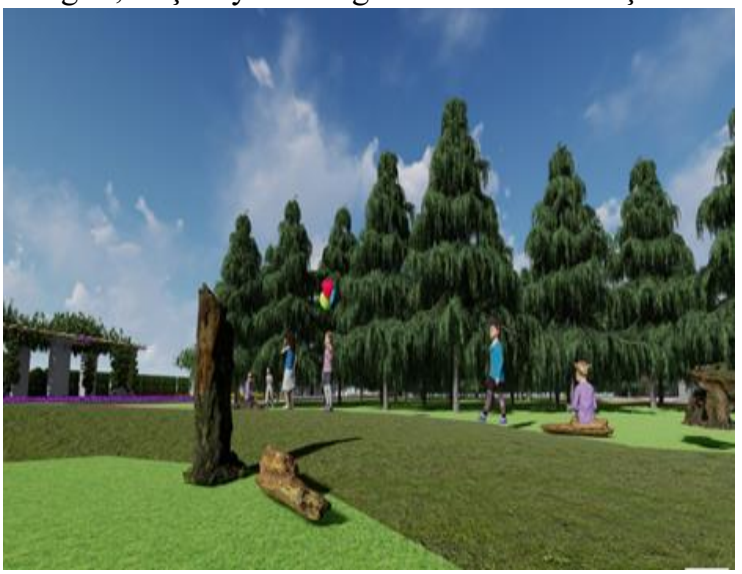

Şekil 13. Ekolojik çocuk oyun alanları deneyim sağlayabildikleri bir mekan kurgusunun tasarlanması hedeflenmiştir (Şekil 13). Çocuklar; tohum, yaprak ve toprak kapları ile uğraşarak doğayı deneyimleyerek, çocuklar için bitki dikim parsellerindeki farklı bitkileri tanıması kararı alınmıştır (Şekil 14, Şekil 15).

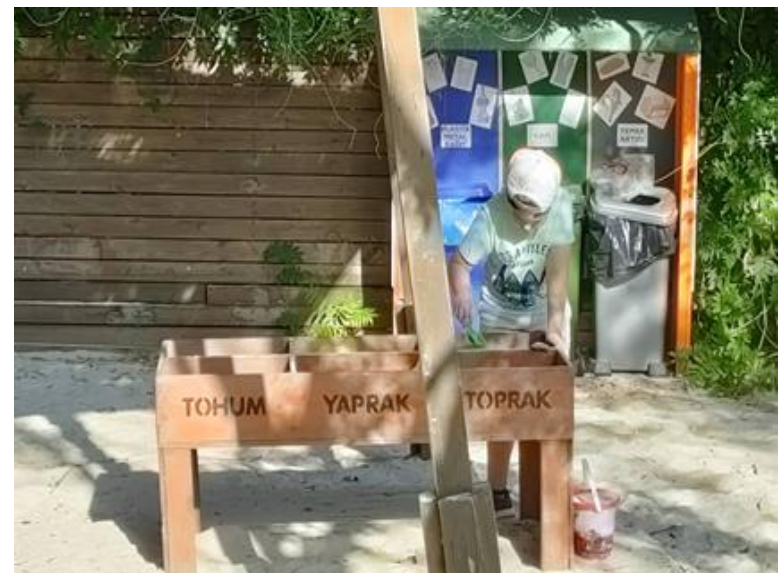

Şekil 14. Çocuklar için tohum, yaprak ve toprak kapları örnek görseli 

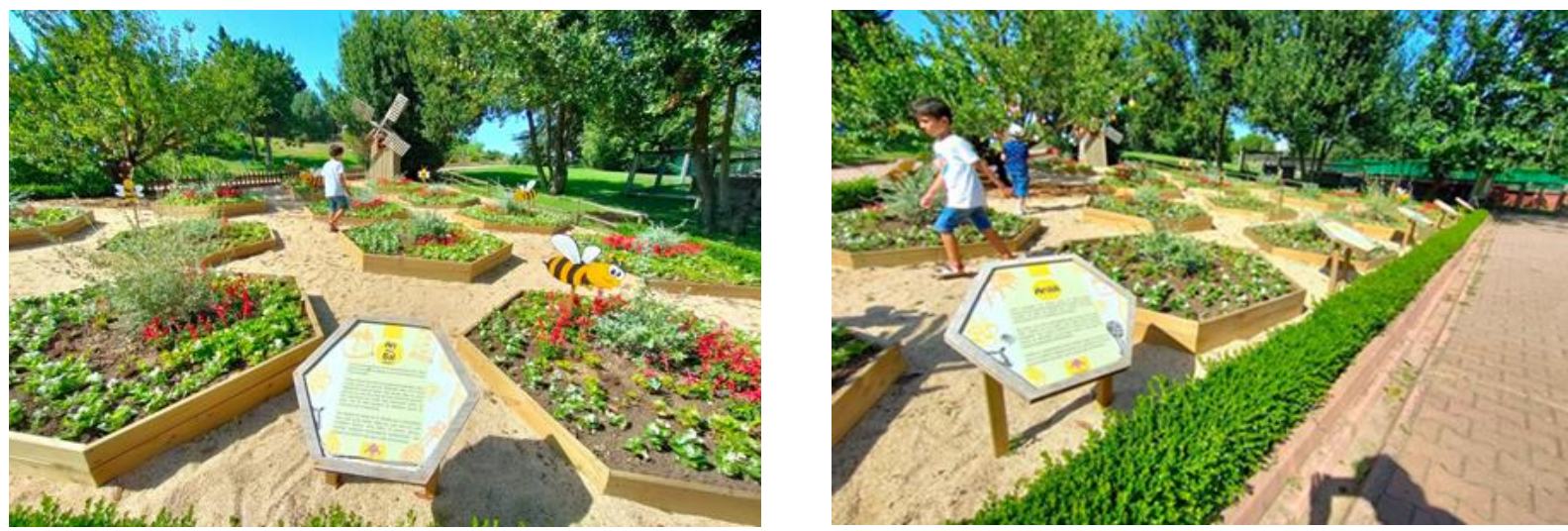

Şekil 15. Çocuklar için bitki dikim parselleri, Nezahat Gökyiğit Botanik Bahçesi (Orijinal)

Ayrıca misafirlerin yeme içme faaliyetlerini karşılayabilecek, restoran ve kafede diğer yapısal elemanları oluşturmaktadır. Restoran ve kafe mevcut bitkisel dokunun yakınında konumlandırılarak, tasarlanan oturma elemanları ile doğal gölgeleme yapılması hedeflenmiştir. (Şekil 16).

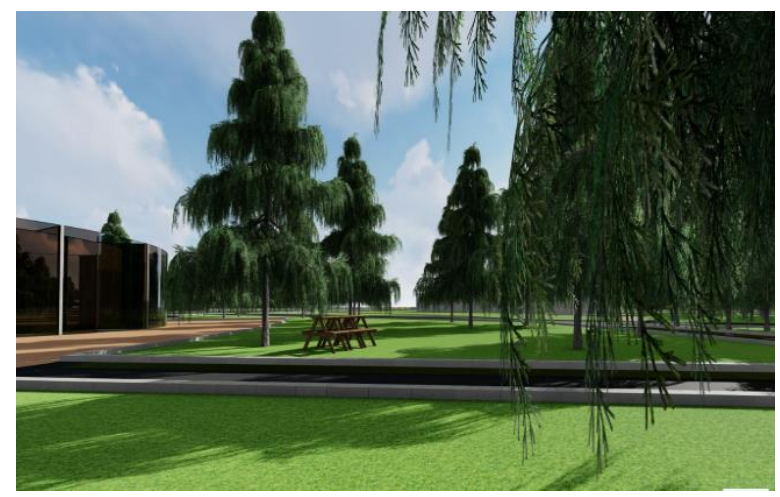

Şekil 16. Kafe ve oturma birimleri

\subsubsection{Toplanma Meydanı, Tıbbi Aromatik Ürün Satış} Birimleri ve Gölgeleme Birimi

Girișten alana girildiğinde bir toplanma meydanı insanları karşılarken, bu alanda etkiyi arttıracak, mekana serinlik ve hareket katacak su ögesinin tasarımı uygun bulunmuştur (Şekil 17). Ayrıca girişte yer alan toplanma meydanının çevresine; yetiştirilen tıbbi ve aromatik bitkilerden oluşan ürünlerin satış1 için ticari birimler oluşturulmuştur.

Çalışma alanının ortasında mevcutta bulunan 50 metre genişliğindeki sert zemine; yeşil doku ve gölgeleme birimi getirilerek yumaşatılması kararı alınmıştır. Gölge biriminin tasarımı yapılarak sarmaşıkların kullanılması uygun bulunmuştur (Şekil 18).

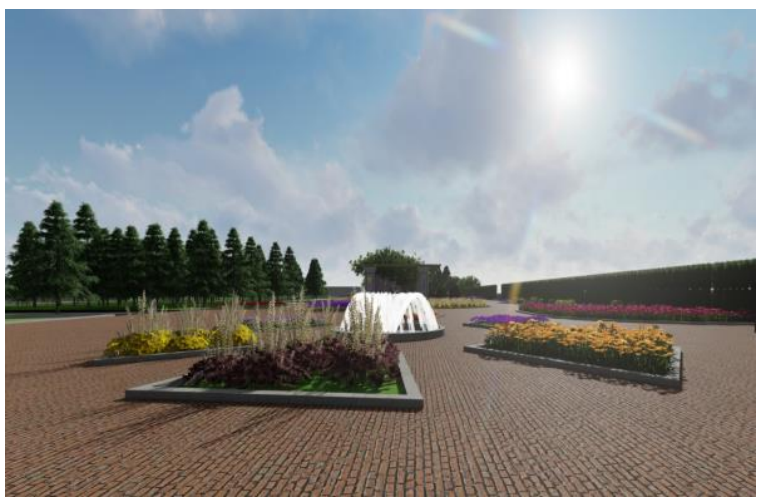

Şekil 17.Toplanma meydanı
Gölgeleme biriminin taşıyıcı ayaklarında Şanlıurfa yöresinde doğal yayılış gösteren gösterişli geofitlerin silüetleri kullanılmıştır. Bu geofitler; Centaurea obtusifolia (Boiss. \& Hausskn.) Wagenitz, Hyacinthella nervosa (Bertol.) Chouard, Muscari comosum (L.) Mill.'dır. Taşıyıcı ayakların bu bitki türleri ile süslenmesi ile hem bitki tanıtımlarının yapılması, hem de alana canlılık getirmesi amaçlanmıştır. Gölge biriminin yapım malzemesi olarak yörenin yerel malzemesi olan urfa taşı tercih edilmesi, bitki figürlerin işlenmesi için kırık seramik parçalarının mozaik şeklinde yapıştırılması önerilmektedir. Böylece mekana renk verilerek, canlılık ve hareketlilik sağlanmış olacaktır. Bu teknikle yapılan Barselona'da Antoni Gaudi tarafindan tasarlanan Park Güell en popüler ikonlardandır.

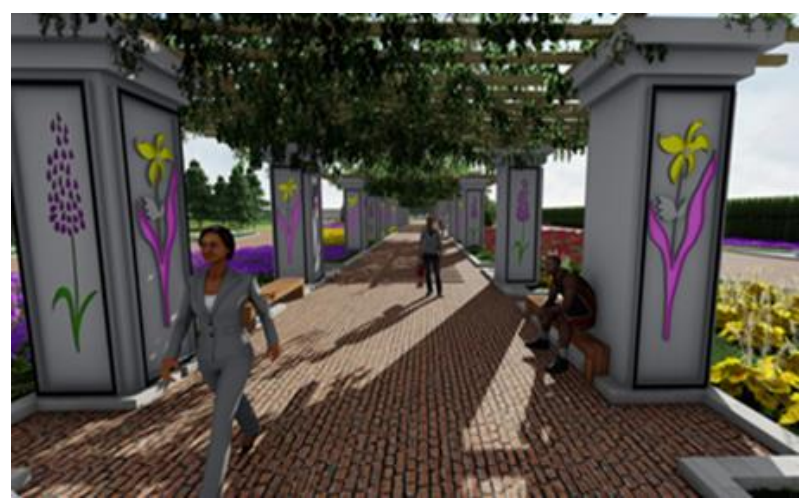

Şekil 18. Tasarımı yapılan gölge birimi 


\subsubsection{Terapi bahçesi}

Terapi bahçeleri, stresi azaltan, dikkati toparlayan, pozitif duygu ve düşünceye katkı sağlayan ortamlardır. Tıbbi aromatik bitkilerin renkleri ve kokuları bireylerde huzur, sakinlik, rahatlama sağlarken, yaşlı bireylerde fiziksel ve ruhsal rahatlamalara neden olmaktadır (Ulrich, 2002).

Terapi bahçesi olarak saptanan alan çalışma alanının kuzeyinde tıbbi aromatik bitki yetiştirme tarlaları ile sınır oluşturan alandır. $\mathrm{Bu}$ alanın yerinin tespitinde, insan sirkülasyonun az olması ve görsel açıdan engin bir manzara seyri sunması etkili olmuştur.Bu alanda, kaya bahçesine, doğal su elemanına ve doğal yürüyüş yollarına yer veren bir tasarım geliştirilmiştir.

\subsection{Bitkisel Tasarım}

Tıbbi ve aromatik bitki bahçelerinin en önemli unsuru tıbbi aromatik bitkiler ve o yörede doğal yayılış gösteren bitkilerin oluşturduğu yaşam ortamlarına önem verilmesidir. Alan daha önce üniversite yerleşkesi olarak kullanıldığından burada var olan bitki türleri bulunmakta olup, mevcut bitkilerin korunması gerektiğinden bu türler olduğu gibi korunması kararı geliştirilmiştir. Korunan bu bitkilere ek olarak, tasarım ana konsepti olan tıbbi aromatik bitkilerin kullanılması uygun bulunmuştur.

Türkiye'de tıbbi bitkilerin önemi kavranarak ıslah çalışmalarına hız verilmiştir. Türkiye'de anason, rezene, kişniş, nane, fesleğen, çörekotu, çemen, kırmızıbiber, yağ gülü, çay, kudret narı, şerbetçi otu çemen, haşhaş, kimyon, safran Kekik, anason ve kişniş çok uzun zamandır kültürü yapılan tıbbi ve aromatik bitkilerdir. Bunlara zaman içerisinde; biberiye, ekinezya, kebere, kekik, lavanta, papatya, şekerotu, çöven, sarı kantaron gibi bazı yeni bitkiler de eklenmiştir. Kardelen, salep, göl soğanı, yılanyastığı, yılan bıçağı, zambak, ters lale ve lale gibi soğanlı bitkiler de yeni kültür bitkileri arasındadır. Ancak bunlar içerisinde en yaygın olarak yetiştirilen tür kekik olup, diğerlerinin üretimleri henüz ihtiyacı karşılamamaktadır (Arslan ve ark., 2015). Şanlıurfa'da Gaptaem tarafından tıbbi ve aromatik bitkilerin üretimi ile ilgili başlatılan çalışmada; Lavandula angustifolia Mill. (lavanta), Thymbra spicata L. var. Spicata (Zahter, kekik), Melissa officinalis L. (Oğulotu, Melisa), Salvia officinalis (ada çayı), Stevia rebaudiana Bertoni (şeker ot), Mentha piperita L. (nane), Nigella spp (çörek otu) ve Thymus spp.( Kekik) gibi bitkilerin üretimi yapılarak; Şanlıurfa kenti için uygulanabilir olduğu görülmüştür (Anonim 2020).

Güneydoğu Anadolu Bölgesi'nde Şanlıurfa'da bulunup ihracatı yapılan tıbbi aromatik bitkiler ise ; Capparis spinosa L. var. spinosa (Sahil keberi), Capparis ovata Desf. var. palaestina Zoh. (Kara keber), Thymbra spicata L. var. spicata (Zahter, kekik, kara kekik), Glycyrrhiza glabra L. var galabra ve var. glandulifera(meyan), Rhus coriaria L. (sumak), Pistacia khinjuk Stocks (bıttım), Pistacia terebinthus L. ( menengiç), Cerasus mahaleb var. mahaleb (L.) Mill. (Mahlep) bitkileridir (Akan, vd., 2005).

Tibbi Aromatik Bitki Dikim ve sergileme Parsellerine, Şanlıurfa'da doğal yayılış gösteren tıbbi aromatik bitkilerin yanında, bölgenin doğal bitki örtüsünde yer almayan ancak tıbbiaromatik özelliği ile bölgeye adapte olabilecek türlere de yer verilmiştir. Böylece bitkilerin Şanlıurfa koşullarına uyum sağlayabilme durumları da izlenebilecektir. Ayrıca tıbbi aromatik bitki dikim ve sergileme parsellerinde; bilgi edinme ve uygulama sağlanmış olacaktır.

Tıbbi aromatik bitki dikim ve sergileme parsellerinde bitkilerin dikim alanları; 5 farklı gruba ayrılmıştır. Bunlar; tek yıllık otsu tıbbi aromatik bitkiler adası, çok yıllık otsu tıbbi aromatik bitkiler adası, geofit bitkileri adası ve çalımsı bitkiler ve ağaççıklar adalarıdır. Yapılan araştırma ve literatür taramalarından kullanımı önerilen tıbbi aromatik bitkiler Tablo 3'de verilmiştir (Anonim 2020, Akan, vd., 2005).

Tablo 3. Kullanılması Önerilen Tıbbi Aromatik Bitkiler

\begin{tabular}{l|l}
\hline Tek Yıllık Otsu Tıbbi Aromatik Bitkiler & Çok Yıllık Otsu Tıbbi Aromatik Bitkiler \\
\hline Ocimum basilicum L.(Fesleğen) & Arctium lappa L. (dulavrat otu) \\
\hline Peganum harmala L. (Üzerlik) & Thymus spp.( Kekik) \\
\hline Cuminum cyminum L. (kimyon) & Salvia spp.(Adaçayı) \\
\hline Pimpinella anisum L. (Anason) & Melissa officinalis L. (Oğul otu) \\
\hline Coriandrum sativum L.(kişniş) & Mentha x piperita (nane) \\
\hline Foeniculum Vulgare Miller (rezene) & Echinacea purpurea (L.) Moench (Ekinezya) \\
\hline Trigonella foenumgraecum L. (çemen) & Sideritis perfoliata L (dağ çayı) \\
\hline Nigella sativa L. (çörek otu) & Helichrysum arenarium (altın Otu) \\
\hline Anethum graveolens L.(dereotu) & Tanacetum parthenium L. (gümüşdüğme) \\
\hline Momordica charantia L.(kudret narı) & Hypericum capitatum var. capitatum(kantoron) \\
\hline Carthamus tinctorius L. (aspir) & \\
\hline Calendula officinalis L. (aynısafa, portakal nergizi) & \\
\hline
\end{tabular}




\begin{tabular}{|c|c|}
\hline Helianthus tuberosus L. (Yer Elması) & \\
\hline Çalı Formundaki Tıbbi Aromatik Bitkiler & Ăgaçcık Formundaki Tıbbi Aromatik Bitkiler \\
\hline Capparis spinosa L. var. Spinosa (Sahil keberi), & Pistacia khinjuk Stocks (bıttım) \\
\hline Capparis ovata Desf. var. palaestina Zoh. (Kara keber) & Pistacia terebinthus L. ( menengiç), \\
\hline Thymbra spicata L. var. spicata (Zahter, kekik) & Cerasus mahaleb var. mahaleb (L.) Mill. (Mahlep) \\
\hline $\begin{array}{l}\text { Glycyrrhiza glabra L. var galabra ve var. Glandulifera } \\
\text { (Meyan) }\end{array}$ & Crataegus monogyna (alıç) \\
\hline Rhus coriaria L. (sumak), & Geofitler \\
\hline Rosa canina (Kuşburnu) & Allium cepa L., \\
\hline Lippia citriodora L. (Limon otu) & Crocus L. (Çiğdem) \\
\hline Lavandula angustifolia Miller (Lavanta) & Orchis L. (Salep) \\
\hline Rosmarinus officinalis L. (Biberiye) & Zingiber officinale (Zencefil) \\
\hline Pelargonium graveolens L. (Itır) & Curcuma longa (Zerdeçal) \\
\hline \multicolumn{2}{|l|}{ Stevia rebaudiana Bertoni L.,(şeker otu) } \\
\hline \multicolumn{2}{|l|}{ Sambucus nigra L. (Kara Mürver) } \\
\hline \multicolumn{2}{|l|}{ Rosa damascena Mill. (Yağ Gülü) } \\
\hline Passiflora spp L. (Çarkıfelek) & \\
\hline
\end{tabular}

Tıbbi aromatik bitkiler bahçesinin giriş ve gölgeleme biriminin çevresinde Şanlıurfa'da doğal yayılış gösteren yerel türlerden, peyzaj açısından renk güzelliği olan, aynı zamanda tıbbi aromatik özellikleri olan fakat bu özelliklerinin fazla değerlendirilmediği türlerin kullanılması önerilmektedir. Yörede doğal yayılış gösteren tıbbi ve aromatik bitkilerin tercih edilmesi çevresel şartlara uyum sağlayarak, bitkisel tasarımın dayanıklılığınıda arttırmaktadır (Bayramoğlu, 2016; Robinson, 2016).
Gelecek ziyaretçilere ve kullanıcıları karşılayan giriş tasarımı yapılırken gölgeleme biriminin kenarlarında Şanlıurfa kentinde doğal yayılış gösteren ve estetik özellikleri olan tıbbi ve aromatik bitkilerin kullanımı tercih edilmiştir. Bu türlere Tablo 4'de yer verilmiştir.

Tablo 4. Şanlıurfa'da Doğal Yayılış Gösteren Tıbbi Ve Aromatik Yerörtücü Bitkiler

\begin{tabular}{l}
\hline Şanlıurfa'da Doğal Yayılış Gösteren Tıbbi Ve Aromatik Yerörtücü Bitkiler \\
\hline Ajuga chamaepitys (L.) Schreb (Acıgıcı) \\
\hline Achillea wilhelmsii C. Koch (Civanperçemi) \\
\hline Linum mucronatum Bertol. (sarıketen) \\
\hline Peganum harmala L. (üzerlik) \\
\hline Geranium tuberosum L. (çakmuz) \\
\hline Galium verum L. - (Boyalık) \\
\hline Acanthus syriacus L. (Suriye ayıpençesi) \\
\hline Salvia multicaulis Vahl. (kürtreyhanı) \\
\hline
\end{tabular}

Bu bitkilerin bu alana dikimi ile halkın bu yöreye ait olan türlere olan farkındalığı artarak kullanımları yaygınlaşacaktır. Alanın doğusunda mevcutta yer alan fabrika ve otopark alanından bu mekanı koparmak ve sınır oluşturmak amacı ile budamaya ve kuraklığa elverişli çit oluşturan ; Cupressus arizonica 'glauca' kullanılması önerilmiştir. Gölge biriminin etrafında görsel anlamda estetik durması açısından Cupressus arizonica 'Glauca' kullanılarak değişik şekillerde budanıp şekil verilmesi uygun bulunmuştur. Gölge biriminin üzerine sarılıcı olarak sarmaşık 
türlerinden Parthenocissus quinquefolia (L.) (Amerikan sarmaşığı önerilmiştir.

\section{Sonuç}

Yerleşke bahçeleri bir kent için oldukça önemli açık yeşil alanlardır. Bu kapsamda çalışmada değerlendirilen alan Harran Üniversitesi Şair Nabi yerleşkesinde, kullanıcıların isteklerine cevap veren huzurlu açık yeşil alana dönüşümü için “Tibbi Aromatik Bitki Vadisi “ projesi önerilmiştir. Tasarlanan projenin Harran Üniversitesi Rektörlüğü’ne bağlı ilgili birimlerle yapılan istişareler, yönetiminin talepleri, finansal faktörler ele alınmıştır. Hazırlanan projenin üniversite yönetimine sunumu gerçekleştirilmiş olup, Şanlıurfa Büyükşehir Belediyesi ve Harran Üniversitesi işbirliği ile yapımı öngörülmektedir.

Proje uygulaması tamamlandığında öğrencileri, akademik/idari personel ve aynı zamanda halkın kullanımına da sunularak, çevre ile uyumlu, tıbbi ve aromatik bitki çeşitliliğine yer verilen, sürdürülebilir, güvenli ve estetik, ekolojik ve fonksiyonel, iklim şartlarına dayanıklı, alana yapısal yük getirmeyen, üniversite kimliğine ve prestijine katkı sağlayan bir peyzaj tasarımı ortaya çıkacaktır. Önerilen projede tıbbi ve aromatik bitki dikim ve sergileme parselleri, ekim ve yetiştirme alanları, üretim serası, tıbbi ve aromatik bitki işleme fabrikası, giriş ve danışma birimi, ekolojik okul ve restoran, toplanma meydanı, tıbbi aromatik ürün satış birimleri, gölgeleme birimi, terapi bahçesi gibi kullanımlara yer verilmiştir.

Projenin uygulanması ile;

- S Şanlıurfa kenti ve GAP ölçeğinde önemli bir açık yeşil alanın oluşumuna katkı sağlanacaktır.

- Tıbbi aromatik türler kullanıcılara tanıtılarak, biyolojik çeşitlilik korunarak sürdürülebilirliği sağlanacaktır.

- Tibbi ve aromatik bitkilerin kullanımı, değerlendirilmesi ve üretimi sağlanabilecektir. Bu bitkilerden çay, baharat, aromatik su, çeşni, uçucu yağ, pomat, macun, parfüm, krem, ilaç vb. maddeler elde edilerek ekonomiye kazandırılması mümkün olabilecektir.

- Şanlıurfa'da yöresinde doğal olarak yayılış gösteren tıbbi aromatik yer örtücü bitkilerin kullanımı önerilmektedir. Doğal yayılış gösteren türler için ex-situ koruma alanı olacaktır. Aynı zamanda yörede çok fazla bilinmeyen tıbbi aromatik bitki türlerine karşı halkın farkındalığı artarak, doğa bilgisi ve çevre bilincinin gelişmesine yardımcı olacaktır.

- Harran Üniversitesi personel, öğrencileri ve farkl1 kurumlarda çalışanlar için bilimsel araştırmalara olanak sağlanacaktır. Bunun yanında; biyoloji, eczacılık, ziraat mühendisliği, peyzaj mimarlı̆̆ 1 , tıbbî ve aromatik bitkiler vb. bölümler için staj olanağı sunulabilecektir.

- Çocuklar için toprağa dokunma, bitki dikimi ve yetiştirme olanağına sahip olurken, çocukların ekolojik bilgisi artacaktır.

- Bitki fotoğrafçılığı, terrarium, aromatik bitki festivalleri vb. etkinliklere ev sahipliği yapılabilecektir.
- Yerleşke içindeki atıl durumdaki fabrikalar işlev kazanarak, tıbbi aromatik bitkileri işleyen fabrikaya dönüşüp, ekonomiye katkı sağlayacak.

Bu projenin sağlıklı yürütülebilmesi için; yönetim, organizasyon, tanıtım, kontrol ve hizmetler sektörü, araştırma merkezi müdürlüğü oluşturularak, geleceğe yönelik geniş vizyonlu planlama çalışmaları yapılmalıdır.

Sonuç olarak, Şanlıurfa'da tıbbi aromatik bitki bahçesinin kurulabilmesi için Harran Üniversitesi ve Şanlıurfa Büyükşehir Belediyesi konunun önemini kavrayarak bir girişim başlatmış olup, çalışmalar devam etmektedir. Özellikle bu konuda yerel, yazılı ve görsel basının, sivil toplum örgütlerinin de içinde olacağ 1 geniş kapsamlı kamuoyu oluşturularak, gerekli maddi destek sağlanmalıdır.

\section{Teşekkür}

Çalışmanın 3 boyutlu görsellerinin yapımında desteklerini esirgemeyen Mimar İbrahim Akgül'e teşekkür ederiz

\section{Kaynakça}

Akan, H., Aslan, M., \& Balos, M. M. (2005). GAP yöresindeki tıbbi ve aromatik bitkiler. TUBITAK Proje No: TBAG/Ç. SEK, 22, 103-T009.

Arslan, M. (2010). Tıbbi ve aromatik bitki türlerinin peyzaj mimarlığı çalışmalarında kullanım olanakları. IV. Süs Bitkileri Kongresi bildiriler kitabı içinde, (ss. 265-270) Mersin: Alata Bahçe Kültürleri Araştırma Enstitüsü.

Arslan, N., Baydar, H., Kızıl, S., Karık, Ü., Şekeroğlu, N., \& Gümüşçü, A. (2015). Tibbi aromatik bitkiler üretiminde değişimler ve yeni arayişlar. Türkiye Ziraat Mühendisliği VIII. Teknik Kongresi, 12-16.

Anonim(2020).https://arastirma.tarimorman.gov.tr/gaptaem/Hab er/84/Sanliurfada-Tibbi-Ve-Aromatik-Bitki-Atagi

Anonim (2021A) "Doğu Karadeniz Bölgesi Tıbbi Ve Aromatik Bitkilerin Envanterinin Çıkarılması, Ticari Kullanımının Araştırılması Ve Üreticilerin Eğitimi Projesi Ar-Ge Bahçelerinin Kurulumu Ve Üreticilerinin Eğitimi”" https://www.dokap.gov.tr/Upload/Genel/dokap-tab-sektoranalizleripdf-242109-rd 55.pdf

Anonim (2021B). TC Tarım ve Köyişleri Bakanlığı, www.tarim.gov.tr/uretim/bitkisel/yetistiricilik bilgi/aromati k/aromatik.htm

Anonim (2021C) Şanlıurfa Büyükşehir Belediyesi İmar ve Şehircilik Dairesi Başkanlığı verileri

Bayramoğlu, Elif (2016). "Sürdürülebilir Peyzaj Düzenleme Yaklaşımı: KTÜ Kanuni Kampüsü’nün Xeriscape Açısından Değerlendirilmesi”, Artvin Çoruh Üniversitesi Orman Fakültesi Dergisi, 17(2), 119-127.

Baytop, T., (1999). Türkiye'de Bitkiler, ile Tedavi (Geçmişte ve Bugün), 2.Baskı Nobel Tıp Kitapevleri Ltd.Şti. s 3-8, İstanbul.

Bekar, M., \& Sekban, D. Ü. G. (2018). Use of Plants with Color and Olfactory Effect in Landscape Architecture. Science, Ecology and Engineering Research in the Globalizing World, 461.

Çekin, M. D., Alpınar, K., \& Küçük, İ. (2016). Zeytinburnu Tıbbi Bitkiler Bahçesi. Ístanbul: Zeytinburnu Belediyesi Kültür Yayınları, (35).

DÖNMEZ, Ş., ÇAKIR, M., \& Şeyma, K. E. F. (2016). Bartın'da yetişen bazı tıbbi ve aromatik bitkilerin peyzaj mimarlığında 
kullanımı. Mimarlık Bilimleri ve Uygulamaları Dergisi, 1(2), 1-8.

Düzenli, T., Tarakci Eren, E., Akyol, D. (2017). Concept of Sustainability and biophilic design in landscape architecture. The Journal of Academic Social Science, 5, 43-49.

Erbaş, Serhat (2013). Türkiye'nin Bazı Tıbbi Ve Aromatik Bitkileri, Oman ve Su İşleri Uzman Yardımcısı, Ankara, 1-58

Ersöz, T., (2012) Bitkisel İlaçlar ve Gıda Takviyeleri İle İlgili Genel Yaklaşım ve Sorunlar, MISED, Sayı : 27-28, s:11-21

Faydaoğlu, Emine, Sürücüoğlu, M. Saip (2011). "Geçmişten Günümüze Tıbbi ve Aromatik Bitkilerin Kullanılması ve EkonomikÖnemi”, Kastamonu Üniversitesi Orman Fakültesi Dergisi, 11(1), 52-67

Fuller, R.A., Invine, K.N., Devine-Wright, P., Warren, P.H., Gaston, K.J., (2007). Psychological benefits of green spaces increase with biodivinity. Biology Letters, 3(4): 390-384.

Gülgün, B., Güney, M., A., Aktaş, E., Yazici, K., (2014). Role of Landscape Architect in Interdisciplinary Planing of Sustainable Cities. Journal of Environmental Protection and Ecology 15, No 4, 1877-1880.

Gülpınar Sekban, D. Ü. (2020). Şifa Bahçelerinin Karadeniz Teknik Üniversitesi Kanuni Kampüsü Çerçevesinde Değerlendirilmesi. Journal of International Social Research, 13(74).

Hepcan, Ç. C., \& Özkan, B. (2005). Botanik bahçelerinin kentsel dış mekânlar olarak kullanıcılara sunduğu olanakların belirlenmesi. Ege Üniversitesi Ziraat Fakültesi Dergisi, 42(3), 159-170.

Keçecioğlu, P. ve Cengiz, G. (2013). İyileştirme bahçelerinde tasarım kriterleri ve bitki kullanımının irdelenmesi. V. Süs Bitkileri Kongresi, 6-9 Mayıs 2013, Yalova.

Kevseroğlu K, Uzun A, Çalışkan V (2014) Orta ve Doğu Karadeniz Bölgesi Doğal Florasında Belirlenen Tibbi ve Aromatik Bitkiler. II. Tibbi Ve Aromatik Bitkiler Sempozyumu Bildiriler Kitab1, Yalova, s. 108-117

Khan IA, Smillie TJ, Craker LE (2005) Quality and Safety Issues Related to Botanicals. Z.E. Gardner (eds.), Acta Hort. 720.

Kırıcı, Saliha (2015). “Türkiye'de Tıbbi Ve Aromatik Bitkilerin Genel Durumu", TÜRKTOB, Türkiye Tohumcular Birliği Dergisi, 4.15 (2015): 4-6.

Kösa S, Güral, S. M. (2019). T1bbi ve aromatik bitkiler ve peyzajda kullanımları. Peyzaj, 1(1), 41-54.

Küçükerbaş, E.V.;Malkoç, E. (2000). Planlama ¥Tasarım, IV. Peyzaj Mimarlığ Kongresi, Ankara, 529-537.

Leszczynski, A. N. (1997). Planting The Landscape A Professional Aproac to Garden Desing. John Wiley and Sons. İnc, $205 \mathrm{p}$.

Marshall, Elaine (2011). "Health And Wealth From Medicinal Aromatic Plants", FAO Diversification Booklet 17. Rural Infrastructure And Agro-Industries Division Food And Agriculture Organization Of The United Nations, Rome 2011. ISSN 1810-0775. Web Site:Http://Www.Fao.Org/Docrep/015/İ2473e/İ2473e00. Pdf

Oğuz, D.; Çakcı, I.; Sevimli G.; Özgür, Ş. (2010).Yaşlı bakım evlerinde diş mekân tasarımı, Yaşlı Sorunları Arastırma Dergisi. (1), 23-33.

Oran (2015). Tibbi ve Aromatik Bitkiler Sektör Raporu, Orta Anadolu Kalkınma Ajansı Kayseri

Pouya, S., \& DEMIR, S. (2017). Peyzaj Mimarlığında Tıbbi Ve Aromatik Bitkilerin Kullanımı. Journal of International Social Research, 10(54).

Robinson, Nick (2016). The Planting Design Handbook, Routledge.
Sağlık, A., \& Kelkit, A. (2015). Çanakkale valiliği hükümet konağı peyzaj tasarım çalışması. Erciyes Üniversitesi Fen Bilimleri Enstitüsü Fen Bilimleri Dergisi, 31(2), 124-128.

Sarı, D., \& Karaşah, B. (2019). İç ve Dış Mekanlarda Kullanılabilecek Tıbbi-Aromatik Bazı Süs Bitkileri. In 4th International Symposium On.

Seçkin, N. P.; Seçkin, Y. Ç.; Seçkin, Ö. B. (2011). Sürdürülebilir Peyzaj Tasarımı ve Uygulama İlkeleri, LiteratürYayınları, İstanbul.

Serez, A. (2011). Tarihsel süreç içinde sağlık bahçeleri (Doktora Tezi, Fen Bilimleri Enstitüsü).

Surat, H. (2020). Artvin'de Doğal Olarak Yetişen Bazı TıbbiAromatik Ve Ekonomik Değere Sahip Odunsu Bitkilerin Peyzaj Mimarlığında Kullanım Alanlarının Değerlendirilmesi. Journal of International Social Research, 13(74).

Temel, M., Tinmaz, A. B., Öztürk, M., \& Gündüz, O. (2018). Dünyada ve Türkiye'de tıbbi-aromatik bitkilerin üretimi ve ticareti. Kahramanmaraş Sütçü Imam Üniversitesi Tarım ve Doğa Dergisi, 21, 198-214.

Ulrich, R. S. (2002). Health benefits of gardens in hospitals. In Paper for conference, Plants for People International Exhibition Floriade (Vol. 17, No. 5, p. 2010).

Yılmaz, S. (2015). Bir Kampüs Açık Mekânın Çevresel Tasarımı: Süleyman Demirel Üniversitesi Orman Fakültesi Binası. Kastamonu University Journal of Forestry Faculty, 15(2), 297-307.

Yılmaz, H. (2019). Atatürk Üniversitesi Merkez Yerleşkesi açıkyeşil alan avlusu peyzaj tasarımı ve uygulama süreci. Akademik Ziraat Dergisi, 8(1), 127-134.

Yılmaz, H., Irmak, M.A. (2012). Yerleşke Planlamasında Bitkisel Tasarım İlkeleri; Atatürk Üniversitesi Yerleşkesi Örneği, Atatürk Üniversitesi Yayınları No:1011, ISBN: 978-975442-184-2

Yoğunlu A (2011) "Fırat Kalkınma Ajansı, Tunceli Ekonomik Değeri Olan Bitkiler Raporu", Sektörel Araştırmalar Serisi-5, Firat kalkınma Ajansı. 1-25. 